\title{
Assessment of soil fertility index for potato production using integrated Fuzzy and AHP approaches, Northeast of Iran
}

\section{Ali Bagherzadeh a,b,*, Amin Gholizadeh a, Ali Keshavarzi c}

aDepartment of Agriculture, Mashhad Branch, Islamic Azad University, Mashhad, Iran

bArid Environments Research Center, Mashhad Branch, Islamic Azad University, Mashhad, Iran

${ }^{c}$ Laboratory of Remote Sensing and GIS, Department of Soil Science, University of Tehran, Karaj, Iran

\begin{abstract}
Considering the important role of soil fertility and nutrient management in the modern agriculture seems to be a key step in appropriate site-specific fertilizers management for crop production. The present study was conducted to prepare a soil fertility zonation map based on soil nutrient elements including total nitrogen, available potassium and phosphorus, magnesium, manganese and iron and soil chemical parameters comprising cation exchange capacity, organic carbon, salinity and pH by integrated Fuzzy and AHP approaches for potato production in Rokh plain, northeast of Iran. In this regard the most important soil chemical parameters and nutrient elements in 0-30 cm depth of the soil was analyzed and mapped. The S-shaped fuzzy membership function was subsequently defined for each factor to fuzzify soil fertility parameters. The soil fertility map was prepared by weighing factor layers by the AHP approach and summation of factor layers by IDW interpolation function in GIS. The values of the soil fertility index in the scale of 0 to 1 ranged from 0.104 to 0.574 , classified the study area in very low $\left(922.90 \mathrm{~km}^{2}\right)$, low $\left(566.10 \mathrm{~km}^{2}\right)$ and moderate fertility $\left(14.86 \mathrm{~km}^{2}\right)$ classes which comprises $61.37 \%, 37.64 \%$ and $0.99 \%$ of the surface area, respectively. A regression between soil fertility values and potato yield in the study area revealed a high correlation $\left(\mathrm{R}^{2}=0.91\right)$ between the observed results which validate the zonation of the fertility classes in the region.
\end{abstract}

\section{Article Info}

Received : 23.10 .2017

Accepted : 26.02.2018

Keywords: Potato, fuzzy, AHP, fertility index, Rokh plain.

(C) 2018 Federation of Eurasian Soil Science Societies. All rights reserved

\section{Introduction}

The rapid growth of population demands higher land use efficiency to ensure food security. The most appropriate way to reach this goal is to increase yield per unit area rather than by expansion of cultivated areas. In this regard, evaluating soil fertility and productivity is of great importance in plant production. Determining the degree of soil fertility was done based on soil chemical parameters including cation exchange capacity (CEC) and Organic carbon (OC) as key indicators of soil quality, soil salinity (ECe) and $\mathrm{pH}$, as well as macro nutrient elements including nitrogen $(\mathrm{N})$, phosphorus $(\mathrm{P})$, potassium $(\mathrm{K})$ and magnesium (Mg) due to high rate of consumption and their great effect on crop yield and its quality, and micro nutrient elements comprising, manganese $(\mathrm{Mn})$ and iron (Fe) because of their important role in conducting physiological processes in plant nutrition (Westermann, 2005). Nutrition of the potato (Solanum tuberosum L.) crop is characterized by its shallow rooting habit and rapid growth rate. Therefore, high yields necessitate an adequate supply of nutrients throughout the growth period. Nitrogen application promotes early development of the foliage and therefore, of the photosynthetic capacity during the growth period. However, excess $\mathrm{N}$ may delay tuber initiation and so reduce yield. The $\mathrm{N}$ requirement depends on many

\footnotetext{
${ }^{*}$ Corresponding author.

Department of Agriculture, Mashhad Branch, Islamic Azad University, P.0 Box: 91735-413, Mashhad, Iran / Arid Environments Research Center, Mashhad Branch, Islamic Azad University, Mashhad, Iran 
factors including soil type and cropping system. A preceding legume or another crop with high residual effects, or an application of organic manure, can reduce fertilizer $\mathrm{N}$ requirements by $40-50 \mathrm{~kg}^{-h a^{-1}}$. Potatoes utilize both ammonium and nitrate $\mathrm{N}$, but show a preference for ammonium, especially in the early stages of growth. Usually, the entire $\mathrm{N}$ is applied to the seedbed. However, in high rainfall conditions, a split application may reduce leaching losses. $\mathrm{N}$ applications after the start of tuber development may delay crop maturity. Potatoes need a good supply of readily available Phosphorous because their root system is not extensive and does not readily utilize less available $\mathrm{P}$ forms. Water-soluble $\mathrm{P}$ is the most efficient source for potatoes. Potassium plays a major role in starch production by the potato crop. Potato plants well supplied with $\mathrm{K}$ are found to withstand frost better than low $\mathrm{K}$ plants. Fertilizer $\mathrm{K}$ requirement depends on soil type and organic manure application. Irrigation can improve the availability of soil $\mathrm{K}$, and there can be varietal differences in susceptibility to K deficiency. Magnesium is the central part of the chlorophyll molecule, where photosynthesis occurs. It also helps the plant metabolize energy and form protein. Magnesium deficiency can occur on leached, sandy soils with low cation exchange capacities and may be intensified by large K fertilizer applications. It can be controlled by $\mathrm{Mg}$ applied in amendments such as dolomite or by Mg-containing fertilizer materials. Manganese (Mn) is involved in chlorophyll formation, nitrate assimilation, enzyme systems, and iron metabolism. Manganese deficiency is generally caused by a high soil $\mathrm{pH}$, whereas $\mathrm{Mn}$ toxicities occur at low soil pH. Iron ( $\mathrm{Fe}$ ) is used in chlorophyll and protein formation, enzyme systems, respiration, photosynthesis, and energy transfer. Iron deficiency is believed to be caused by an imbalance of metallic ions, such as $\mathrm{Cu}$ and $\mathrm{Mn}$; excessive amounts of $\mathrm{P}$; and a combination of high $\mathrm{pH}$, high lime, cool temperatures and high levels of carbonate in the root zone. Soil application or foliar sprays are the widely used methods for supplying micro-nutrients. The micro-nutrient needs of potato can also be met simply by soaking the seed tubers in nutrient solutions. The non-dormant seed tubers are soaked in $0.05 \%$ micronutrient salt solutions for three hours. The deficiencies of $\mathrm{Mn}$ and Fe are controllable by soil or foliar application. Potato cultivars can differ markedly with regard to their sensitivity to micronutrient deficiencies.

Fuzzy model is one of the most flexible models used to provide different kinds of soil maps (Cassel-Gintz et al., 1997). The model comprises high accuracy for preparing the soil attribute maps (Kremenová, 2004). Fuzzy set theory and concept of a linguistic variable is derived values of variables and made its use for expanded application area. Fuzzy logic makes conversion of imprecise information to precise one, consists of capability to design rational decisions containing imperfect information. Uncertainty, imprecision, incompleteness, risk management, partial true and vice versa is an attribute of information in Fuzzy systems. The fuzzy logic design is the best approach to get precise, accurate result and conclusions. Fuzzy set theory has been used in environmental sciences including land suitability evaluation, soil fertility classification, soil geo-statistics and soil quality indices (Burrough, 1989; McBratney and Odeh, 1997; McBratney et al., 2003; Zhang et al., 2004; Lagacherie, 2005). The development of fuzzy logic-based soil fertility mapping techniques is due to its ability to represent the continuous nature of soil spatial variation (Zhu et al., 2001; Yang et al., 2007). Fuzzy set theory has been widely used in soil fertility classification, mapping and land evaluation (McBratney et al., 2003; Zhang et al., 2004; Lagacherie, 2005; Sanchez Moreno, 2007). The analytical hierarchy process (AHP) developed by Saaty (1980) is a multi-criteria evaluation approach, used to enhance with fuzzy factor standardization. The AHP plays an important role in selecting alternatives (Dey and Ramcharan, 2008), (Vahidnia et al., 2009). AHP has become one of the most widely used methods for the practical solution of multi criteria decision making issues (Chan et al., 2000; Chang et al., 2007). AHP uses understanding and informed knowledge without the need of specific data (Bottero et al., 2011). But the main shortage of AHP is that it deals with people's expert judgment as a crisp number between 1 and 9 and their Eigen values, this doesn't handle the uncertainty associating to these judgments. In order to overcome that incompetence, Fuzzy set integrated with AHP technique to determine the best alternative (Levary and Wan, 1998), (Chang et al., 2007). The combination of fuzzy set and AHP leads to more flexibility in judgment and decision making. The AHP reflects human thinking as it uses approximate information and uncertainty to generate decision in addition to inheritance of the advantages of AHP, ease of handling qualitative and quantitative data, use of hierarchical structure, pairwise comparison, reduce inconsistency, and generates priority vectors (Vahidnia et al., 2009). The main hypothesis behind our research is that there is a logical relationship between the soil chemical properties, soil fertility index and crop yield which can be defined as a modeling by integrating Fuzzy and AHP approaches. The aim of the present study is to evaluate soil fertility and classification for potato production in Rokh plain, northeast of Iran. In this regard integration between Fuzzy and AHP approaches and GIS was used to produce and classify soil fertility zonation map for the study area. 


\section{Material and Methods}

\section{General characteristics of the study area}

The present study was conducted in Rokh plain, Khorasan-e-Razavi Province, Northeast Iran (Figure 1). The study area is located between latitude $35^{\circ} 28^{\prime} 51^{\prime \prime} \mathrm{N}$ to $35^{\circ} 47^{\prime} 45^{\prime \prime} \mathrm{N}$ and longitude $58^{\circ} 34^{\prime} 49^{\prime \prime} \mathrm{E}$ to $59^{\circ} 35^{\prime} 39^{\prime \prime} \mathrm{E}$ including lands less than $2933 \mathrm{~m}$ asl. The general physiographic trend of the plain extends in a west-east direction with a maximum length of $92 \mathrm{~km}$. The total surface of the study area comprises $1503.86 \mathrm{~km}^{2}$. The elevation values of the study area vary between $1386 \mathrm{~m}$ and $1901 \mathrm{~m}$ asl, with an average of $1643.5 \mathrm{~m}$ asl. The main land use practice in the study area is irrigated farming. The climate of the study area is semi-arid with mean annual precipitation of $267.7 \mathrm{~mm}$ and means annual temperature of $14.3^{\circ} \mathrm{C}$ (Figure 1 ).

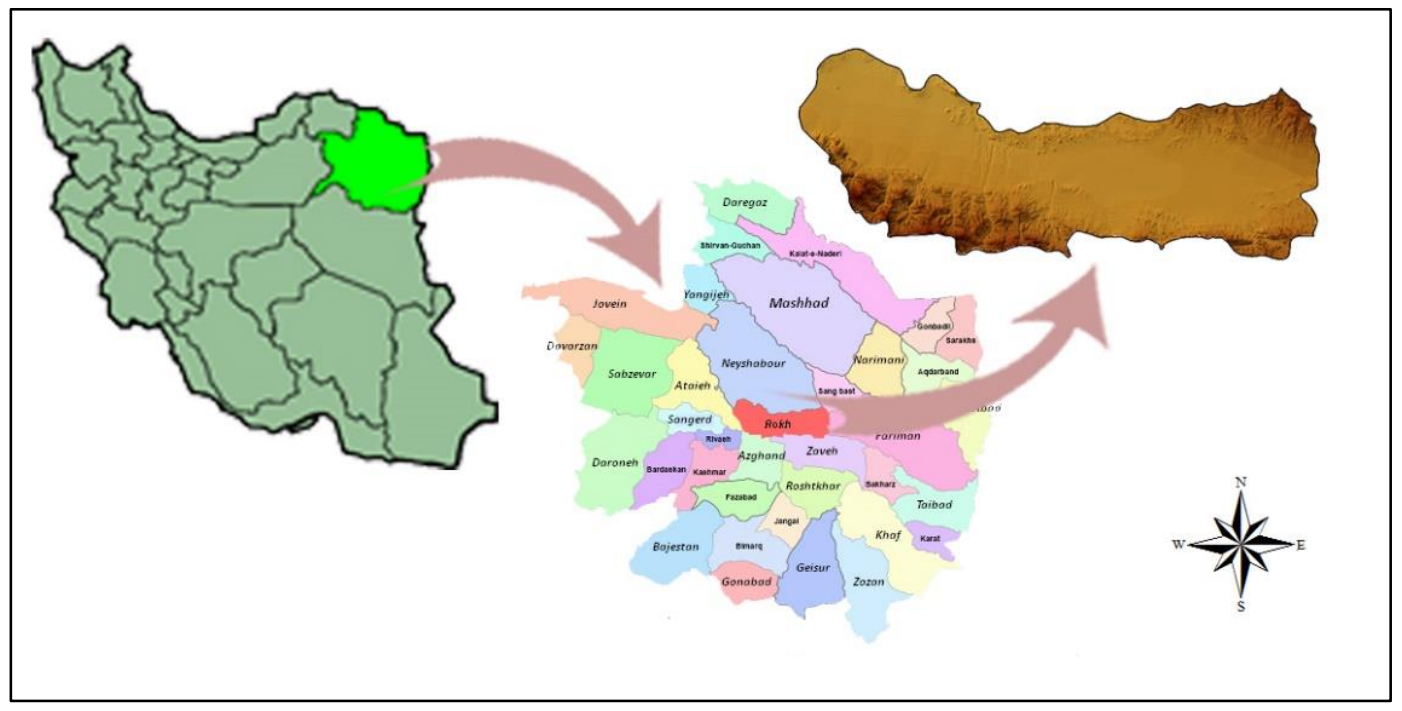

Figure1. the Geographical location of the study area

\section{Soil analysis}

Some 300 soil samples in depth of $0-30 \mathrm{~cm}$ were collected from current potato fields all over the study area. The values of Cation Exchange Capacity (CEC), Electro Conductivity of soil saturated extract $\left(\mathrm{EC}_{\mathrm{e}}\right.$ ) and soil pH were determined by Ammonium Acetate method, Electro Conduct-meter and standard $\mathrm{pH}$ meter, respectively. The Soil organic carbon was measured using the Walkley Black method (Walkley and Black, 1934). The total N (\%) was determined using the electro ultra-filtration (EUF) apparatus with an autoanalyzer, the available P was determined using the blue color method of Murphy and Riley (1962) and the absorbance measured on spectronic-20 equipment. The available $\mathrm{K}$ was determined by flame photometer approach and the $\mathrm{Mg}$ values were analyzed by spectrophotometer through CFA method. The atomic absorption spectrophotometer (AAS) was used for measuring manganese and iron. The cumulative quantities of the nutrients desorbed after 10, 30 and 35 min were subsequently calculated.

\section{Fuzzy set theory}

The fuzzy set theory originated by Zadeh (1965). Fuzzy set theory is a mathematical method used in data and functional relationships to characterize uncertainty and imprecision. To characterize uncertainty using standard statistical measures using a fuzzy set is useful (e.g., Mean, standard deviation, and distribution type). The fuzzy set theory includes fuzzy mathematics, fuzzy measures, fuzzy integrals, etc. One of the aspect of the field of fuzzy mathematics is fuzzy logic. In classical set theory, the membership of a set is defined as true or false, 1 or 0 . Membership of a fuzzy set, however, is expressed on a continuous scale from 1 to 0 that $\mu \mathrm{A}=0$ means that the value of $x$ does not belong to $\mathrm{A}$ and $\mu \mathrm{A}=1$ means that it belongs completely to $A$. A fuzzy set $A$, defined in the total space $X$, is a function defined in $X$ which assumes values in the range $[0,1]$. A fuzzy set (A) may be defined as follows (Burrough et al., 1992):

$$
\text { For each } \mathrm{A}=\{x, \mu \mathrm{A}(\mathrm{x})\} \mathrm{x} \in \mathrm{X}
$$

Where, $\mathrm{X}=\{x\}$ is a finite set of points and $\mu \mathrm{A}(x)$ is a membership function of $x$ in $\mathrm{A}$.

The membership function describes the variable's membership assigned to A and, therefore, it may quantify the influence of the variable $\mathrm{x}$ on the predicted phenomenon, as it is grasped by the developer (Burrough et al., 2015). There are several fuzzy membership function that in the paper was used Linear membership 
function. The Fuzzy Linear transformation function applies a linear function between the user-specified minimum and maximum values. Any value below the minimum will be assigned as 0 (definitely not a member) and any value above the maximum as 1 (definitely a member) (Sys et al., 1993; Sanchez Moreno, 2007). Fuzzy membership functions have been linear for the majority of soil factors, hence the $S$-shaped built-in membership function was defined as Equation 1 (Oberthur et al., 2000). This spline-based curve is a mapping on the vector $\mathrm{x}$, and is named because of its $\mathrm{S}$-shape. The parameters $\mathrm{a}$ and $\mathrm{b}$ locate the extremes of the sloped portion of the curve, as given by: $y=\operatorname{smf}(x,[a b])$ (Figure 2 ).

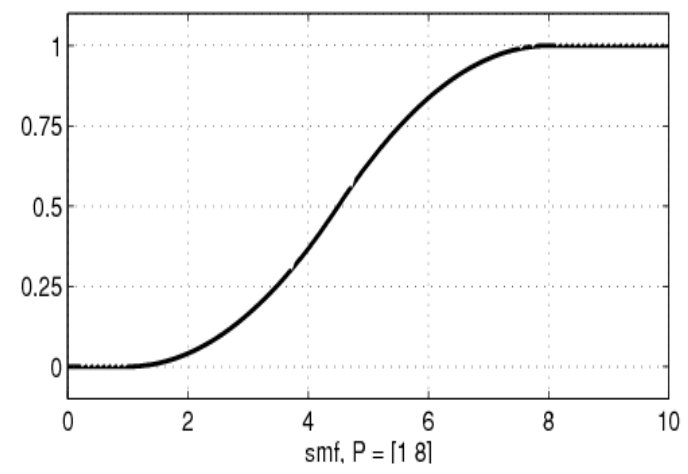

$$
f(x ; a, b)=\left\{\begin{array}{cc}
0, & x \leq a \\
2\left(\frac{x-a}{b-a}\right)^{2}, & a \leq x \leq \frac{a+b}{2} \\
1-2\left(\frac{x-b}{b-a}\right)^{2}, & \frac{a+b}{2} \leq x \leq b \\
1, & x \geq b
\end{array}\right\}
$$

Figure 2. The S-Shaped membership function and its equation

The applied function is asymmetrical linear where $a$ and $b$ are the critical and adequacy value limits used for each of the ten factors (Table 1).

Table 1. Soil fertility factors and the critical values (mangle and adequacy limits) in the fuzzy membership function (the values of $a$ and $b$ are calculated based on 40 t.ha-1 potato production).

\begin{tabular}{llcc}
\hline Fertility factors & units & $a$ & $b$ \\
CEC & meq/100g & 7 & 18 \\
OC & $\%$ & 0.86 & 1.29 \\
$\mathrm{EC}_{\mathrm{e}}$ & $\mathrm{dS} \mathrm{m} \mathrm{N}^{-1}$ & 1.7 & 6 \\
$\mathrm{~N}_{\text {total }}$ & $\%$ & 0.05 & 0.2 \\
$\mathrm{~K}$ & $\mathrm{mg} \mathrm{kg}^{-1}$ & 40 & 110 \\
$\mathrm{pH}$ & - & 5.2 & 8.2 \\
$\mathrm{P}$ & $\mathrm{mg} \mathrm{kg}^{-1}$ & 6 & 15 \\
$\mathrm{Mg}$ & $\mathrm{mg} \mathrm{kg}^{-1}$ & 10 & 20 \\
$\mathrm{Mn}$ & $\mathrm{mg} \mathrm{kg}^{-1}$ & 3 & 6 \\
$\mathrm{Fe}$ & $\mathrm{mg} \mathrm{kg}^{-1}$ & 2 & 4 \\
\hline
\end{tabular}

\section{Analytical Hierarchy process (AHP)}

The AHP developed by Saaty (1990) considers a one-level weighting system through a pair wise comparison matrix between the parameters as described by Saaty $(1990,1994)$ and Saaty and Vargas (2001). The method employs an underlying nine-point recording scale to rate the relative preference on a one-to-one basis of each criteria (Malczewski, 1999). For better map presentation purposes, the scale assigns a linguistic expression to each corresponding numerical value (Table 2).

Table 2. The Saaty scale (2003) was used for generation of pairwise comparison matrix.

\begin{tabular}{ll}
\hline Intensity of importance & Definition \\
\hline 1 & Equal importance \\
2 & Equal to moderate importance \\
3 & Moderate importance \\
4 & Moderate to strong importance \\
5 & Equally preferred \\
6 & Strong to very strong importance \\
7 & Very strong importance \\
8 & Very to extremely strong \\
9 & Extreme importance \\
\hline
\end{tabular}

The weights of factors are calculated from the pair-wise comparison matrix undertaking specific values and vectors calculation. It has been demonstrated that the specific vector corresponding to the largest specific value of the matrix provides the relative priorities of the factors, i.e., if one factor has preference; its specific 
vector component is larger than that of the other. The components of the specific vector sum to unity. Thus, a vector of weights is obtained, which reflects the relative importance of the various factors from the matrix of paired comparisons. The complete pair-wise comparison matrix contains many multiple paths by which the relative importance of factors can be assessed; therefore, it is also possible to determine the degree of consistency that has been used in developing the judgments. In the construction of the matrix of paired comparisons, the consistency of the judgments should be revealed because this matrix is a consistent matrix. The results of the pair-wise comparison matrix and the factor weights are shown in Table 3.

Table 3. Pair-wise comparison matrix for calculating factor weights

\begin{tabular}{|c|c|c|c|c|c|c|c|c|c|c|c|}
\hline Parameters & CEC & OC & $\mathrm{EC}_{\mathrm{e}}$ & $\mathrm{N}$ & $\mathrm{K}$ & $\mathrm{pH}$ & $\mathrm{P}$ & $\mathrm{Mn}$ & $\mathrm{Zn}$ & $\mathrm{Fe}$ & Weight \\
\hline CEC & 1.00 & & & & & & & & & & 0.282 \\
\hline OC & 0.33 & 1.00 & & & & & & & & & 0.199 \\
\hline $\mathrm{EC}_{\mathrm{e}}$ & 0.33 & 0.50 & 1.00 & & & & & & & & 0.154 \\
\hline $\mathrm{N}$ & 0.33 & 0.33 & 0.50 & 1.00 & & & & & & & 0.122 \\
\hline K & 0.20 & 0.33 & 0.33 & 0.33 & 1.00 & & & & & & 0.076 \\
\hline $\mathrm{pH}$ & 0.20 & 0.20 & 0.33 & 0.33 & 0.50 & 1.00 & & & & & 0.063 \\
\hline$P$ & 0.20 & 0.20 & 0.25 & 0.33 & 0.50 & 0.50 & 1.00 & & & & 0.050 \\
\hline $\mathrm{Mg}$ & 0.13 & 0.14 & 0.14 & 0.17 & 0.20 & 0.20 & 0.25 & 1.00 & & & 0.023 \\
\hline $\mathrm{Mn}$ & 0.11 & 0.13 & 0.13 & 0.14 & 0.20 & 0.20 & 0.25 & 0.50 & 1.00 & & 0.018 \\
\hline $\mathrm{Fe}$ & 0.11 & 0.13 & 0.13 & 0.13 & 0.17 & 0.17 & 0.20 & 0.33 & 0.50 & 1.00 & 0.014 \\
\hline
\end{tabular}

In AHP method, an index of consistency, known as the consistency ratio (CR), is a ratio between the matrix's consistency index and random index. CR is used to indicate the probability that the matrix judgments were randomly generated (Malczewski, 1999).

$$
C R=\frac{C I}{R I}
$$

where RI is the average of the resulting consistency index depending on the order of the matrix given by Malczewski (1999) and CI is the consistency index and can be expressed as

$$
C I=\frac{\lambda \max -n}{n-1}
$$

Where, $\lambda \max$ is the largest or principal specific value of the matrix and can be easily calculated from the matrix, and $\mathrm{n}$ is the order of the matrix. CR ranges from 0 to 1 . A CR close to 1 indicates the probability that the matrix's rating was randomly generated. A CR of 0.10 or less is a reasonable level of consistency (Malczewski, 1999). A CR above 0.1 requires revision of the judgments in the matrix. The calculated value of $\mathrm{Cr}$ in our study was 0.056 . Once a satisfactory CR is obtained, the resultant weights are applied. The weights should add up to a sum of 1.0, as the linear weighted combination calculation requires. It was shown that the most important factor affecting soil fertility was cation exchange capacity (CEC) with the weight of 0.282 and the least important factor was defined as Iron with the weight of 0.014 . Finally, in order to finalize soil fertility map the values obtained by AHP with the fuzzy values of each affecting parameters. In this procedure the values obtained by fuzzification of each parameter is multiplied in the factor weight of that parameter and the summations of the resultant values is used to produce the final soil fertility map as shown in the following equation (Kremenová, 2004):

$$
\begin{gathered}
\mu_{A}=w_{i} \mu_{A 1}+\cdots+w_{k} \mu_{A 1} \\
\mu_{A}=\sum_{j=1}^{k} w_{j} \mu_{A j(\mathrm{x})} \quad \mathrm{x} \in \mathrm{X} \\
\sum_{j=1}^{k} W_{j}=1 \quad \mathrm{~W}_{\mathrm{j}}>0
\end{gathered}
$$

Where; $\mu$ is the membership function related to each of the parameters and $W$ is the specific weight given to each of the parameters. The analytical procedures in this study including interpolation, fuzzy mapping and final soil fertility map calculations have been done using Arc map (Version 10.5) software. The flowchart of the fuzzy AHP procedure used for soil fertility zonation in our study has been shown in Figure 3. 


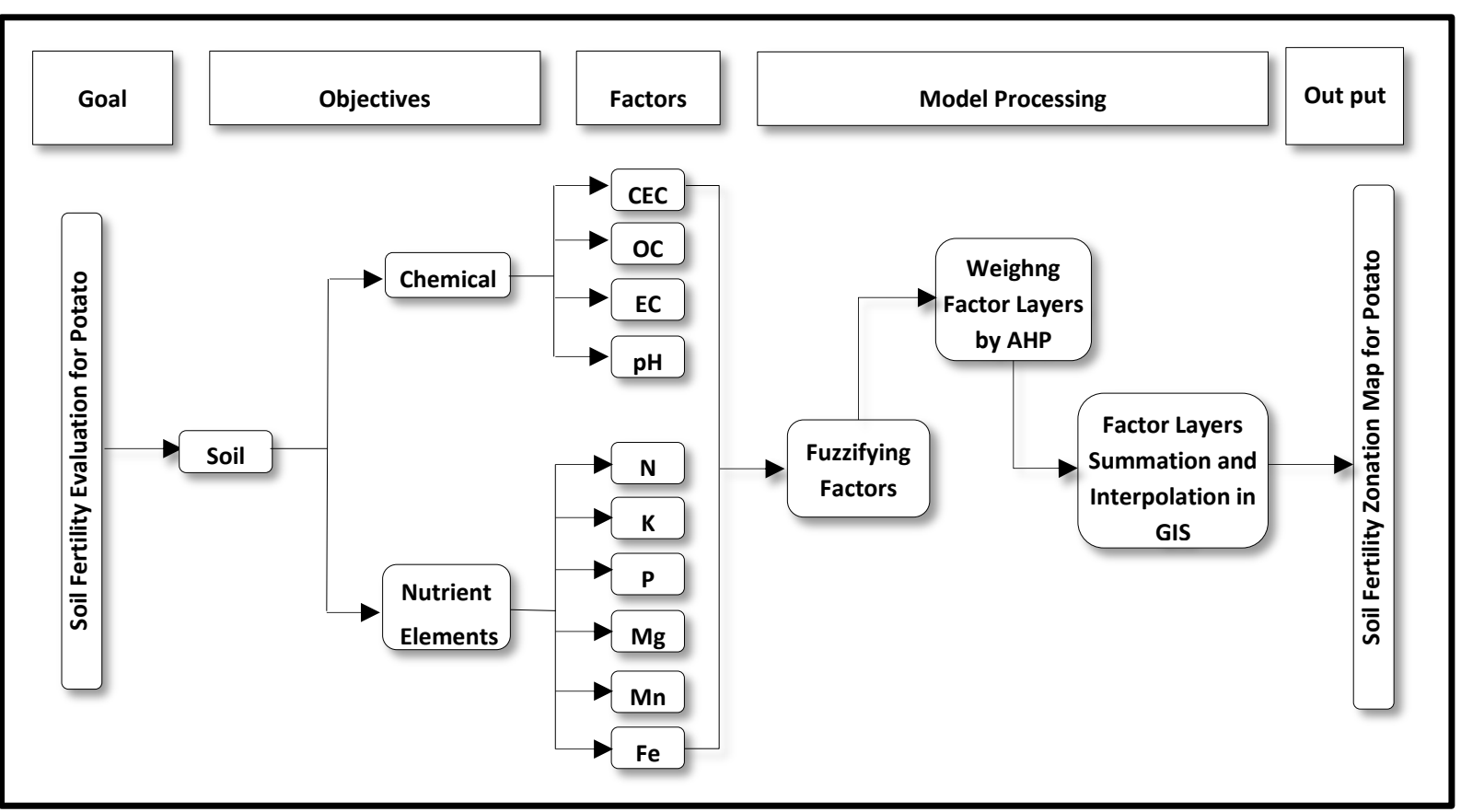

Figure 3. Schematic diagram of the Fuzzy-AHP Model for preparing soil fertility zonation

\section{Results}

\section{Spatial distribution of factors affecting soil fertility}

Soil chemical parameters including cation exchange capacity (CEC), organic carbon (OC), soil salinity (EC e, $_{\text {, }}$ $\mathrm{pH}$ and six nutrient elements including total Nitrogen $(\mathrm{N})$, Potassium (K), Phosphorous (P), Magnesium (Mg), Manganese ( $\mathrm{Mn}$ ) and Iron (Fe) were analyzed and their spatial distribution in the upper $30 \mathrm{~cm}$ of the soil was mapped (Figure 4, 5).

The zonation of soil chemical parameters in the study area
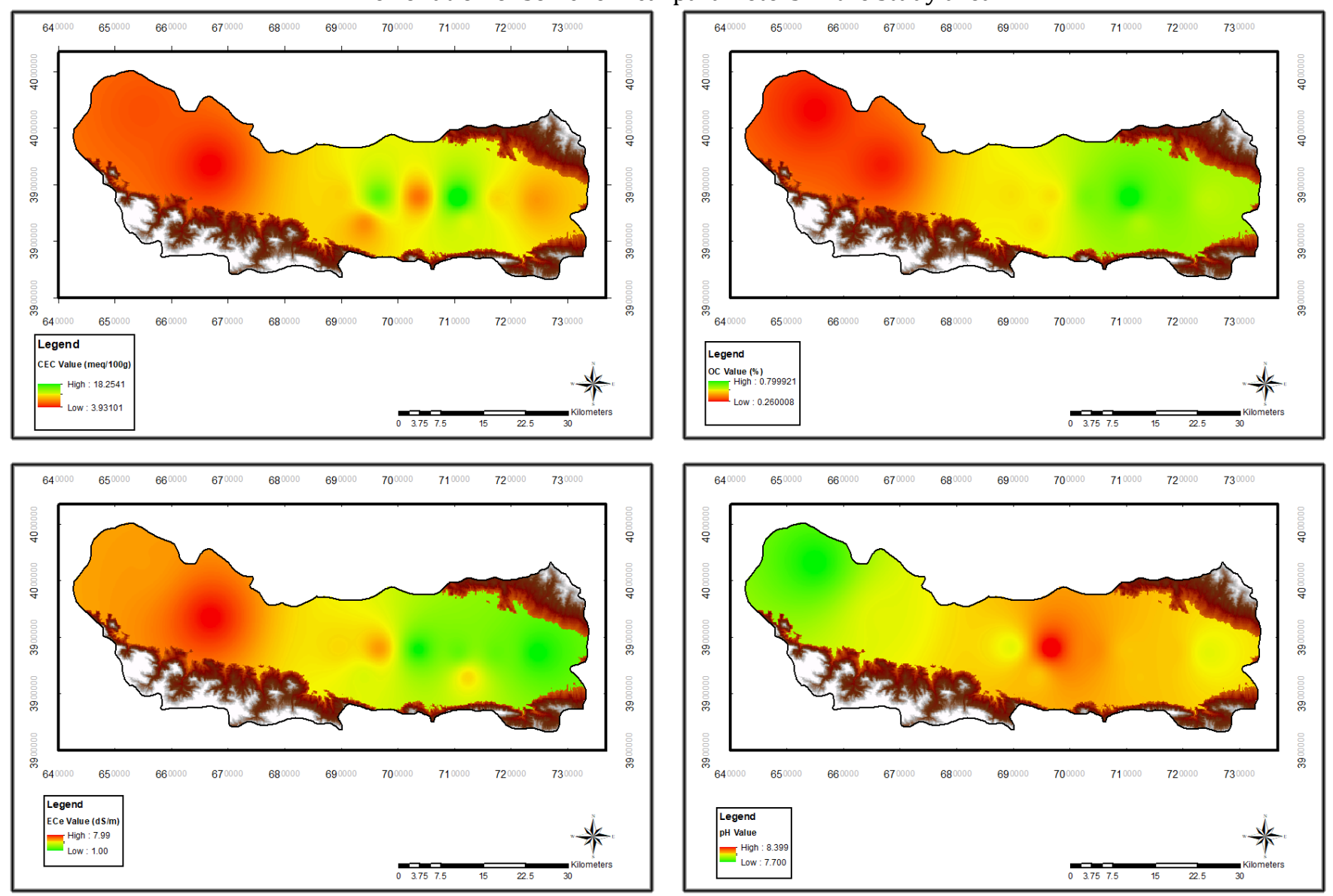

Figure 4. The zonation of soil chemical parameters in the study area 

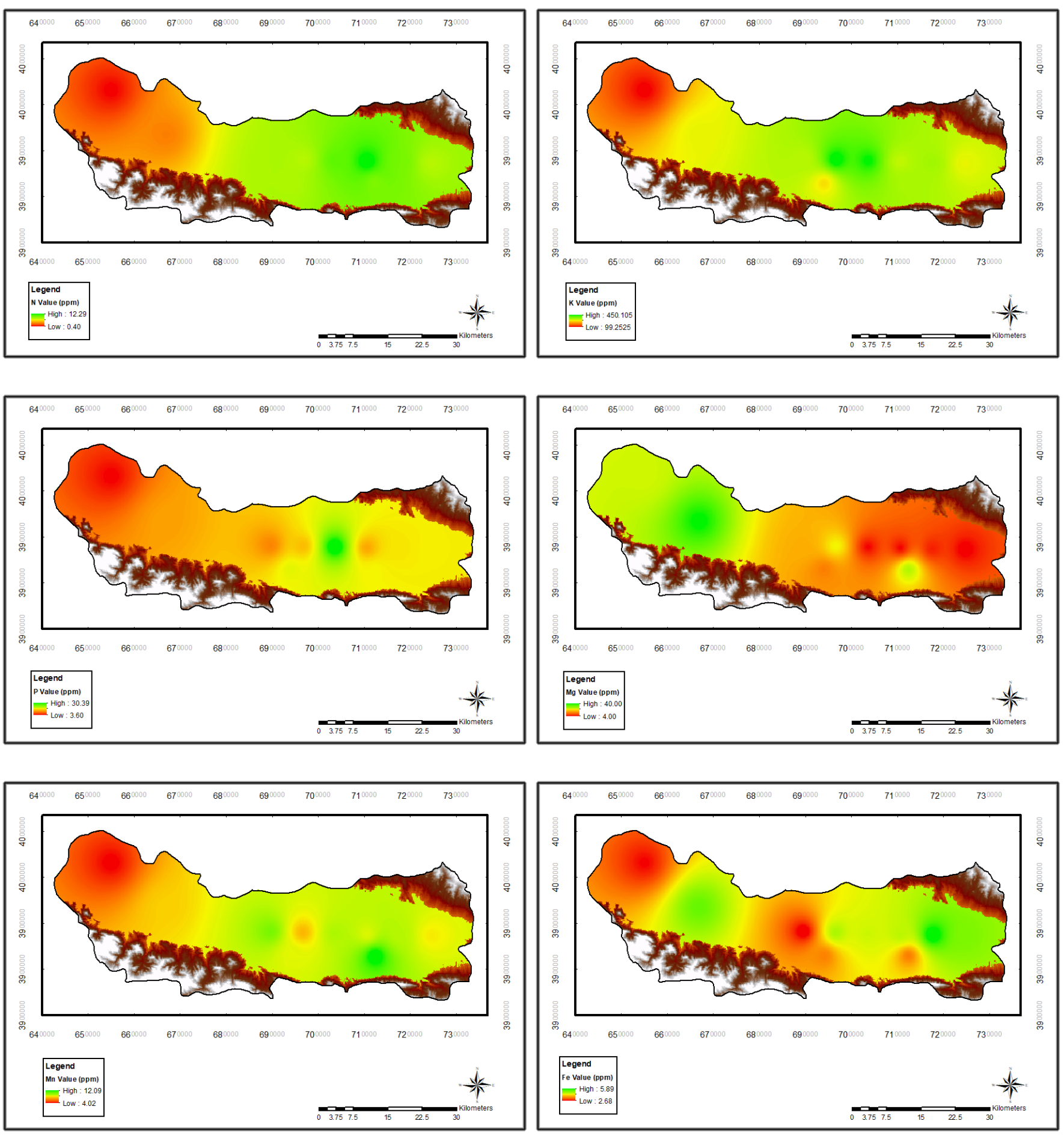

Figure 5. The zonation of soil nutrient elements in the study area

The main physiological functions of the selected nutrient elements in potato have been shown in Table 4 . The values of cation exchange capacity in the study area varied between 6.23 and $13.8 \mathrm{meq} / 100 \mathrm{~g}$. The higher values of CEC were found mainly in west, while in east parts of the study area due to lower values of soil organic carbon and light texture of the soil the values of CEC were found as very low. The values of organic carbon in the study area ranged from 0.26 to $0.80 \%$. The spatial distribution of soil organic carbon was followed the same pattern as CEC. The upper values of OC were observed in north and west, while the lower values were found mainly in the middle and south parts of the study area. The $\mathrm{EC}_{\mathrm{e}}$ values ranged from $1 \mathrm{dS} \mathrm{m}^{-1}$ in some areas in the west to $8 \mathrm{ds} \mathrm{m}^{-1}$ in the north of the study area. It was revealed that the values of $\mathrm{EC}_{\mathrm{e}}$ in west of the study area were in tolerance threshold for potato production; however to compensate the negative effects of high soil salinity and alkalinity on potato production a distinct amount of granulated sulfur were applied to soil before planting. The values of $\mathrm{pH}$ varied between 7.7 in west to 8.4 mainly in the middle of the study area. Potato grows best on slightly to moderately acid soils although it grows 
successfully in soils with a wide $\mathrm{pH}$ range, but in base soil reaction of our study area its negative effects on the availability of phosphorous and micronutrients such as manganese and iron cannot be ignored. It was revealed that the values of mineral nitrogen at the study area were very low, ranged from 0.4 to $12.3 \mathrm{mg} . \mathrm{kg}^{-1}$. The upper values of total $\mathrm{N}(\%)$ were found in east and the lower values were distributed mainly in west of the study area. The values of available phosphorous in the study area ranged from 3.6 to $25.2 \mathrm{mg}$. $\mathrm{kg}^{-1}$. The lower values of available $\mathrm{P}$ were observed in the west and the higher values were found mainly in east parts of the study area. The values of available potassium varied between 99.24 and $450.15 \mathrm{mg} . \mathrm{kg}^{-1}$. The lower values of available $\mathrm{K}$ were found in the west and the higher values were observed in the middle and east of the plain. The values of magnesium varied between 4.0 and 28.0 mg.kg- ${ }^{-1}$ The lower values of $\mathrm{Mg}$ were observed in the east and the higher values were found in west of the study area. The values of manganese ranged from 4.02 to $12.10 \mathrm{mg}^{\mathrm{kg}}{ }^{-1}$. The upper values of Mn were observed in the middle and east, while the lower values were found in west of the study area. The values of Iron ranged from 2.68 to $5.90 \mathrm{mg} . \mathrm{kg}^{-1}$. The lower values of Fe were found in west and some parts in the middle of the plain and the upper values were observed mainly in east of the study area.

Table 4. The main functions of nutrients elements in Potato

\begin{tabular}{ll}
\hline Nutrient & Function \\
\hline Nitrogen (N) & Synthesis of proteins (growth and yield). \\
Phosphorus (P) & Cellular division and formation of energetic structures. \\
Potassium (K) & Transport of sugars, stomata control, cofactor of many enzymes, reduces \\
Magnesium (Mg) & susceptibility to plant diseases. \\
Manganese (Mn) & Central part of chlorophyll molecule. \\
Iron (Fe) & Necessary in the photosynthesis process. \\
\hline
\end{tabular}

\section{Soil fertility index zonation}

The soil fertility factors including chemical and nutrient elements were fuzzified by S-shaped membership function (Figure 2). To determine the degree of membership for each factor the critical and adequacy values $a$ and $b$ were defined based on 40 t.ha $^{-1}$ potato production. The pairwise comparison matrix was used by AHP approach to give the appropriate weight to each factor layer (Table 3). To determine the final soil fertility zonation for potato production the summation operator was used in GIS to combine the weighted layers in a final soil fertility map (Figure 6). The values of soil fertility index in the scale of 0 to 1 ranged from 0.104 to 0.574 which classified as very low to moderate fertility (Table 5). Based on our results the soil fertility classes were categorized in very low $\left(922.90 \mathrm{~km}^{2}\right)$, low $\left(566.10 \mathrm{~km}^{2}\right)$ and moderate fertility $(14.86$ $\mathrm{km}^{2}$ ) which comprises $61.37 \%, 37.64 \%$ and $0.99 \%$ of the surface area, respectively. A linear regression between soil fertility values and the potato yield at each point study revealed a high correlation $\left(\mathrm{R}^{2}=0.91\right)$ between the observed results which verify the zonation of the fertility classes in the region.

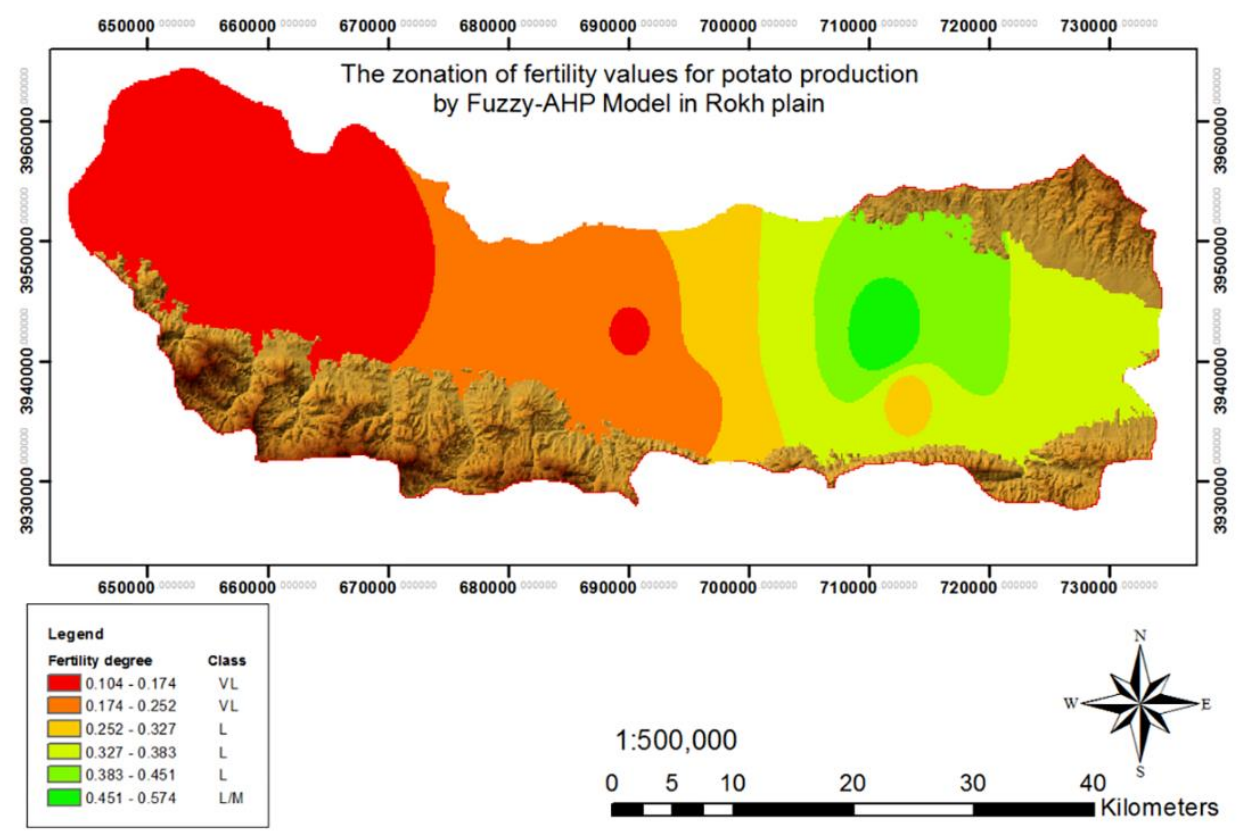

Figure 6. The zonation of soil fertility values for Potato production by Fuzzy-AHP approach in Rokh plain 
Table 5. The values of soil fertility and the corresponding fertility classes

\begin{tabular}{cl}
\hline Fertility Value & Fertility Class \\
\hline $0.00-0.25$ & Very Low (VL) \\
$0.25-0.50$ & Low (L) \\
$0.50-0.75$ & Moderate (M) \\
$0.75-0.90$ & High (H) \\
$0.90-1.00$ & Very High (VH) \\
\hline
\end{tabular}

\section{Discussion}

To determine the soil fertility index and preparing a soil fertility zonation map for potato cultivation in Rokh plain, northeast of Iran, we applied an integrated Fuzzy and AHP approach. On this basis the most important soil chemical parameters and nutrient elements in 0-30 cm depth of the soil were analyzed and mapped. For fuzzifying each soil fertility parameter, a S-shaped fuzzy membership function was defined. The soil fertility map was prepared by weighing factor layers by the AHP approach and summation them by IDW interpolation function in ArcGIS. The values of the soil fertility index in the scale of 0 to 1 ranged from 0.104 to 0.574 , which classified the study area in very low $\left(922.90 \mathrm{~km}^{2}\right)$, low $\left(566.10 \mathrm{~km}^{2}\right)$ and moderate fertility $\left(14.86 \mathrm{~km}^{2}\right)$ classes which comprises $61.37 \%, 37.64 \%$ and $0.99 \%$ of the surface area, respectively. The spatial distribution of classes shows two areas in northwest and southeast as very low fertility zones, while great parts in north to east and some areas in west was demonstrated as low fertility zones for potato production. The poor values of soil fertility in the study area contributed mainly to very low amounts of soil organic carbon and mineral nitrogen which reduces potato yield to 35 tha $^{-1}$ in the study area. Hence, to provide a desirable production of beet the consumption of nitrogen fertilizers as well as organic manures is inevitable. The results of the proposed model agreed with current conditions of potato production in the study area. The zonation of soil fertility for Potato production by integrating Fuzzy and AHP approach in the study area could be helpful in the potato production management decisions. It is proposed that exact fertilization program have to be done according to the specific crop needs, soil and water conditions and the farmers experiences. Our results revealed that the disaggregation of soil fertility variables allows direct evaluation of the contribution that individual components of soil fertility can make to potato yield. Worldwide, many studies have considered the impacts of environmental hazards such as climate change on future agricultural land use through scenario modelling and their consequent policy impacts (e.g. Ewert et al., 2005), but there is limited literature on the impacts of soil fertility rate on the crop production, a key factor influencing a region's ability to adapt agricultural practices to real conditions. But such analyses can play a critical role in formulating future land policies given the multi-functional role of agriculture and its importance for ecosystem services (Winter, 2009). The present study emphasized the importance of developing regional agricultural policy approaches that allow the transfer of indigenous knowledge to farmers, where they do not carry out routine soil nutrients analyses for potato production.

\section{Acknowledgements}

We thank Islamic Azad University, Mashhad branch for their support of the project.

\section{References}

Bottero, M., Comino, E., Riggio, V., 2011. Application of the analytic hierarchy process and the analytic network process for the assessment of different wastewater treatment systems. Environmental Modelling and Software 26(10): 1211-1224.

Burrough, P.A., 1989. Fuzzy mathematical methods for soil survey and land evaluation. European Journal of Soil Science 40(3): 477-492.

Burrough, P.A., MacMillan, R.A., van Deursen, W., 1992. Fuzzy classification methods for determining land suitability from soil profile observations and topography. European Journal of Soil Science 43(2): 193-210.

Burrough, P.A., McDonnell, R.A., Lyoyd, C.D., 2015. Principles of geographical information systems. $3^{\text {rd }}$ Edition, Oxford University Press, UK. 317p.

Cassel-Gintz, M.A., Lüdeke, M.K.B., Petschel-Held, G., Reusswig, F., Plöchl, M., Lammel, G., Schellnhuber, H.J., 1997. Fuzzy logic based global assessment of the marginality of agricultural land use. Climate Research 8(2):135-150.

Chan, F.T.S., Chan, M.H., Tang, N.K.H., 2000. Evaluation methodologies for technology selection. Journal of Materials Processing Technology 107(1-3): 330-337.

Chang. N.B., Parvathinathan. G., Jeff. B.B., 2007. Combining GIS with fuzzy multicriteria decision-making for landfill siting in a fast-growing urban region. Journal of Environmental Management 87(1): 139-153.

Dey, P.K., Ramcharan, E.K., 2008. Analytic hierarchy process helps select site for limestone quarry expansion in Barbados. Journal of Environmental Management 88(4): 1384-1395. 
Ewert, F., Rounsevell, M.D.A., Reginster, I., Metzger, M.J., Leemans, R., 2005. Future scenarios of European agricultural land use: I. Estimating changes in crop productivity. Agriculture, Ecosystems \& Environment 107(2-3): 101-116.

Kremenová, 0., 2004. Fuzzy modeling of soil maps. McS Thesis. Helsinki University of Technology, Department of Surveying, Finland. p 81

Lagacherie, P., 2005. An algorithm for fuzzy pattern matching to allocate soil individuals to pre-existing soil classes. Geoderma 128: 274-288.

Levary, R.R., Wan, K., 1998, A simulation approach for handling uncertainty in the analytic hierarchy process. European Journal of Operational Research 106 (1): 116-122.

Malczewski, J., 1999. GIS and multicriteria decision analysis. John Wiley \& Sons Inc. 392p.

McBratney, A.B., Mendonca Santos, M.L., Minasny, B., 2003. On digital soil mapping. Geoderma 117(1-2): 3-52.

McBratney, A.B., Odeh, I.O.A., 1997. Application of fuzzy sets in soil science: fuzzy logic, fuzzy measurements and fuzzy decisions. Geoderma 77(2-4): 85-113.

Oberthür, T., Dobermann, A., Aylward, M., 2000. Using auxiliary information to adjust fuzzy membership functions for improved mapping of soil qualities. International Journal of Geographical Information Science 14(5): 431- 454.

Saaty, T. L. 1980. The Analytic Hierarchy Process McGraw Hill, Inc., New York, 54p.

Saaty, T., Vargas, L.G., 2001. Models, methods, concepts and applications of the analytic hierarchy process. Kluwer Academic Publishers. 333p.

Saaty, T.L., 1990. The analitic hierarchy process in conflict management. International Journal of Conflict Management 1(1): 47-68.

Saaty, T.L., 1994. Fundamentals of decision making and priority theory with the AHP. RWS publications, Pittsburg, Pennsylvania, USA.

Saaty, T.L., 2003. Decision-making with the AHP: Why is the principal eigenvector necessary? European Journal of Operational Research 145(1): 85-91.

Sanchez Moreno, J.F., 2007. Applicability of knowledge-based and fuzzy theory-oriented approaches to land suitability for upland rice and rubber, as compared to the farmers' perception. A case study of Lao PDR. McS Thesis. International Institute for Geo-Information Science and Earth Observation, Enschede, The Netherlands. 133 p.

Sys, C.E., Van Ranst, E., Debaveye, J., Beernaert, F., 1993. Land evaluation. Part III: Crop requirements. Agricultural Publications No.7. G.A.D.C., Brussels, Belgium, 191p. Available at [access date: 23.10.2017]: http://hdl.handle.net/1854/LU-233235

Vahidnia, M.H., Alesheikh, A.A., Alimohammadi, A., 2009. Hospital site selection using fuzzy AHP and its derivatives. Journal of Environmental Management 90 (10): 3048-3056.

Walkley, A., Black, I.A., 1934. An examination of the Degtjareff method for determining soil organic matter and a proposed modification of the chromic acid titration method. Soil Science 37(1): 29-38.

Westermann, D.T., 2005. Nutritional requirements of potatoes. American Journal of Potato Research 82(4): 301-307.

Winter, M., 2009. Agricultural land use in the era of climate change: The challenge of finding 'Fit for Purpose'data. Land Use Policy 26(1): S217-S221.

Yang, L., Zhu, A.X., Li, B.L., Qin, C.Z., Pei, T., Liu, B.Y., Li, R.K., Cai, Q.G., 2007. Extraction of knowledge about soil environment relationship for soil mapping using fuzzy c means (FCM) clustering. Acta Pedologica Sinica 44: 16-23.

Zadeh, A.L., 1996. Fuzzy Sets. In: Fuzzy Sets, Fuzzy Logic, and Fuzzy Systems. Selected papers by Lotfi A.Zadeh. Advances in Fuzzy Systems - Application and Theory, Vol.6. Klir, G.J., Yuan, B. (Eds.). World Scientific Publishing Co Pte Ltd. Singapoure. pp. 394-432.

Zhang,. B., Zhang, Y., Chen, D., White, R.E., Li, Y., 2004. A quantitative evaluation system of soil productivity for intensive agriculture in China. Geoderma 123(3-4): 319-331.

Zhu, A.X., Hudson, B., Burt, J.E., Lubich, K., Simonson, D., 2001. Soil mapping using GIS, expert knowledge, and fuzzy logic. Soil Science Society of America Journal 65(5): 1463-1472. 